\title{
PASTORALISTS' PERCEPTIONS ON AN INVASIVE ALIEN PLANT PARTHENIUM HYSTEROPHORUS AND ITS MANAGEMENT CONTROL IN SIMANJIRO DISTRICT, TANZANIA
}

\author{
Leticia J. Musese ${ }^{*}{ }^{\boxplus}$, Deo D. Shirima ${ }^{1}$, Ramadhan Kilewa ${ }^{2}$ \\ ${ }^{* 1}$ Department of Ecosystems and Conservation, Sokoine University of Agriculture P.O. Box 3010, \\ Morogoro, Tanzania \\ ${ }^{2}$ Tropical Pesticides Research Institute, P.0 Box 3024 Arusha, Tanzania
}

DOI: https://doi.org/10.29121/granthaalayah.v8.i8.2020.816

Article Type: Research Article

Article Citation: Leticia J. Musese, Deo D. Shirima, and Ramadhan Kilewa. (2020). PASTORALISTS' PERCEPTIONS ON AN INVASIVE ALIEN PLANT PARTHENIUM HYSTEROPHORUS AND ITS MANAGEMENT CONTROL IN SIMANJIRO DISTRICT, TANZANIA. International Journal of Research GRANTHAALAYAH, 8(8), 181-189. https://doi.org/10.29121/granthaa layah.v8.i8.2020.816

Received Date: 20 July 2020

Accepted Date: 28 August 2020

Keywords:

Non-Native Plants

Parthenium Weed

Rangeland

Unpalatable Species

\begin{abstract}
The Maasai pastoralist community resides in Simanjiro District, Manyara Region, Tanzania. As a pastoralist community they are largely dependent on rangelands as a source of forage for their livestock. However, plant invasions are threatening rangeland productivity, displacing valuable forage species, leading to a reduction in livestock populations. The noxious weed Parthenium hysterophorus has recently been established in Simanjiro District and may pose a significant threat to livelihoods if effective control strategies are not put in place. This study was therefore conducted to determine pastoralists' understanding of P. hysterophorus in Simanjiro District, Tanzania. Semi-structured and open-ended questionnaires were used to collect information on, among others, the date of introduction, means of spread, area coverage, effects of P. hysterophorus on livestock health and management control for P. hysterophorus. Pastoralists were unaware of when P. hysterophorus was introduced although they mentioned vehicles, people and livestock to be the main vectors of introduction and spread. They confirmed that $P$. hysterophorus has little/some expanding its range since it was first noticed at the beginning of this decade. Furthermore, most pastoralists were not aware of the effects of Parthenium weed in livestock although few reported it causing distasteful and less milk and diarrhoea after consuming the weed. There were no major efforts in place to control Parthenium weed. Therefore, efforts need to be made to motivate pastoralists through community awareness campaigns to impart knowledge on how to control P. hysterophorus to promote rangeland productivity. Also, community awareness the impacts of the weed on their livestock and human health.
\end{abstract}

\section{INTRODUCTION}

Parthenium hysterophorus L. (Asteraceae) is considered to be one of the world's worst invasive plant species (Binu et al., 2010). The weed originated from the Gulf of Mexico (McConnachie et al., 2011) and accidentally introduced to Asia, Australia and Africa where it has created a significant threat to biodiversity and livestock health (Adkins and Navie, 2006). Its ability to adopt and grow under wide climatic condition, soil conditions, production

(C) 2020 The Author(s). This is an open access article distributed under the terms of the Creative Commons Attribution License, which permits unrestricted use, distribution, and reproduction in any medium, provided the original author and source are credited. 
of large number of seeds (about 10,000 to 25,000 seeds per plant) and allelopathic chemicals makes it a successful invader (Kifle et al., 2011).

Parthenium weed has been recorded as having a negative effect on grazing land in Ethiopia (Dhileepan, 2009; Brunel et al., 2004), Central Queensland and New South Wales in Australia (Huy and Seghal 2004); South Africa, Swaziland, Mozambique Zimbabwe, Madagascar, Kenya (McConnachie et al.,2011) and Uganda. Clark and Lotter (2011) reported its presence in Tanzania but yet there is no information of its impact in rangelands. Parthenium weed is toxic to animals causing dermatitis on various animals including horses and cattle (Kaur et al., 2014). Moreover, $P$. hysterophorus has irritating odour, bad taste and hence not preferred by cattle although cattle are habitually forced to feed on it during fodder scarcity (Kumar, 2014).

Majority of people living in semi-arid areas of Tanzania are pastoralists (Yanda and William, 2010). Simanjiro District is one of the semi-arid part of Tanzania occupied by the Maasai pastoralist community (Steven and Rob, 2002).These pastoralists community depends on the rangelands for their natural capital such as meat and milk, source of financial (cash) and social capital (wealth, prestige, identity, respect, friendship, and marriage dowry, festivity) (Yanda and Williams, 2010). Not only Tanzanian pastoralists but also about 70\% of pastoralists in the world depend on rangelands for fodder for their livestock (Sangeda and Malole, 2014).

Pastoral communities have elaborate knowledge of grazing animals and changes in vegetation (Oba and Kaitira, 2006). This knowledge has significant influence on the management strategies of a particular ecosystem for different stakeholders (Kgosikoma et al., 2012). Therefore, it is essential to understand how pastoralists perceive $P$. hysterophorus, and its effect on livestock health and productivity. A better understanding of the environment among both researchers and pastoralists is crucial for sustainable development and environmental conservation (Kessler and Stroosnijder, 2010). The objectives of this study were to determine through questionnaires the i) date of introduction and means of spread of P. hysterophorus, ii) distribution of P. hysterophorus on the rangelands, iii) identify effects of $P$. hysterophorus on livestock health and productivity, and iv) determine control strategies for P. hysterophorus.

\section{MATERIALS AND METHODS}

\subsection{STUDY AREA}

The study was conducted in Simanjiro District, Manyara Region, northern Tanzania (Figure 1). Simanjiro District ( $3^{\circ} 53^{\prime} 9^{\prime \prime}$ to $3^{0} 52^{\prime} 0.01^{\prime \prime} \mathrm{S}$ and $36^{\circ} 36^{\prime} 32^{\prime \prime} \mathrm{E}$ to; $36^{\circ} 36^{\prime} 0.00^{\prime \prime} \mathrm{E}$ ) is a semi-arid area adjacent to the Tarangire National Park (TNP). The area is is characterized by bimodal rainfall, with the main rains from January to March and short rains from September to December (Nyaruhucha et al., 2006). The area comprises predominantly Maasai communities where livestock husbandry is their major activity to support their livelihood with a human population of 178,693 according to the National Census of 2012. 


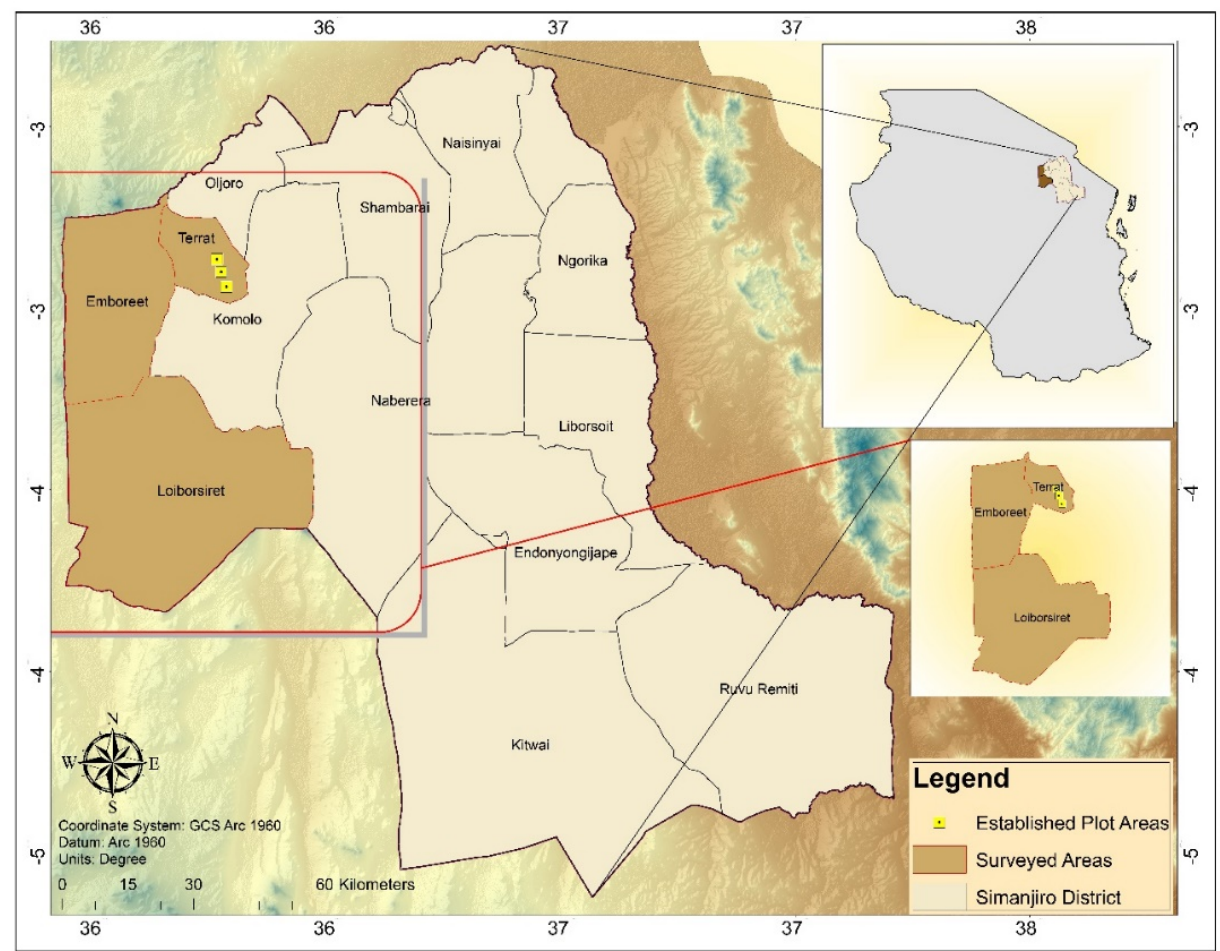

Figure 1.1: Map of the Simanjiro District in Tanzania showing surveyed areas in relation to P. hysterophorus established plots.

\subsection{RESEARCH DESIGN AND SAMPLING PROCEDURE}

The target respondents for the study were pastoralists who graze their livestock in P. hysterophorus infested areas. Respondents were selected through a multi-stage research sampling procedure whereby the first stage involved the selection of the study area, namely Simanjiro District in Manyara Region. The district was selected because of the presence of $P$. hysterophorus within the rangelands and about $90 \%$ of the residents are pastoralists who graze their livestock in an infested rangeland. In stage two, three sites namely Terat, Loiborsiret and Emboreet (Figure 3.1) were purposefully selected on the basis that, pastoralists graze their livestock in the rangeland where $P$. hysterophorus occurred and plots for vegetation data were established (Figure 3.1). A sampling frame for this study was obtained from village registers. A sampling frame is a list that classifies a target respondents/population. A cross-sectional research design was employed whereby data were collected once from selected respondents (Kothari,2004). A total of 120 pastoralists, counting 40 per each site (Terat, Loiborsiret and Emboreet) were selected randomly from the village registers. Basing on literature (Kayunze,1998) 30 respondents are recommended for social survey and in this study a higher number (40 respondents per each site) was adopted. Structured questionnaires were prepared to collect adequate information regarding the perception of pastoralists on the effect of $P$. hysterophorus (Appendix 2). The respondents were household head and first household member who formed part of the sampling units. This was to ensure that different gender perspectives were considered. However, in cases where only one member was found in a household, a single respondent was interviewed.

Table 3.1: Number of respondents in surveyed villages

\begin{tabular}{|c|c|}
\hline Name of village & Number of respondents \\
\hline Terat & 40 \\
\hline Loiborsiret & 40 \\
\hline Emboreet & 40 \\
\hline
\end{tabular}


Pastoralists' perceptions on an invasive alien plant Parthenium hysterophorus and its management control in Simanjiro District, Tanzania

\section{DATA COLLECTION} nature.

In this study both primary and secondary data were used. The data have both quantitative and qualitative

\section{PRIMARY DATA}

Primary data were collected using structured questionnaires that included both open and closed-ended questions. In order to achieve effective communication from the selected pastoralists, prepared questionnaires were pretested. Feedback and comments from the survey were instrumental in improving the efficiency of the data collection tools (questionnaire). In order to collect reliable data, the questions were translated into Swahili language and for those who were not able to understand the Swahili language, questions were translated into Maasai language for easy understanding by the respondents.The questionnaires inquired about pastoralist's perceptions on the invasive weed knowledge, effect of $P$. hysterophorus on livestock and management options for it. Specifically, the questionnaire included questions about; the general issues affecting their livestock, problematic weeds in their grazing land (rangeland), introduction of $P$. hysterophorus, means of spread of $P$. hysterophorus, area covered by $P$. hysterophorus in their grazing land, feeding preferences of the livestock on $P$. hysterophorus and its effect in milk production as well as control of $P$. hysterophorus.

\section{SECONDARY DATA}

Secondary data were obtained through reviewing available information collected from different literature sources such as online journals, articles, published documents and Sokoine National Agriculture Library (SNAL).

\section{Data Analysis}

The objective of data analysis is to summarize collected data and make them useful for informed decision making. A quantitative analysis method was used in this study.

\section{DESCRIPTIVE STATISTICAL ANALYSIS FOR QUANTITATIVE AND QUALITATIVE DATA RESPECTIVELY}

The primary data from questionnaire were coded and entered in a Statistical Package for Social Sciences (SPSS) computer program version 16.0. The output tables were exported to excel spread sheet from where descriptive statistics (frequencies, percentages, and measures of central tendencies) were derived. Results were then presented in form of frequency tables for easy interpretation. The qualitative information obtained from the interviews and direct observations were however transcribed through content analysis.

\section{RESULTS}

\subsection{SOCIOECONOMIC CHARACTERISTIC OF RESPONDENTS}

The study involved both male (52\%) and female (48\%) with an average age between 29 and 39. During survey it was also observed that $75 \%$ of the pastoralists had no formal education while $25 \%$ had only primary education level. Main source of pastoralists income depended on direct selling of livestock (64\%), selling of meat and milk $(21 \%)$ and small businesses (15\%).

\subsection{GENERAL ISSUES AFFECTING LIVESTOCK AND PROBLEMATIC WEEDS IN RANGELAND}

Among the issues reported by the pastoralists affecting their livestock were insufficient grazing land, weeds and poisonous plants (such as Parthenium hysterophorus, Ipomoea hildebrandtii) and somehow stock theft (Table 3.2). Furthermore, pastoralists reported problematic weed affecting livestock in grazing land to be Ipomoea hildebrandtii, Parthenium hysterophorus and Lantana camara (Table 3.2). 
Table 3.2: Pastoralists' response on Issues and problematic weed affecting their livestock

\begin{tabular}{|c|c|c|}
\hline Issues affecting livestock & $\mathrm{n}$ & $\%$ \\
\hline Insufficient grazing & 25 & 21 \\
\hline Weeds and other poisonous plants & 24 & 20 \\
\hline Diseases & 70 & 58 \\
\hline Stock theft & 1 & 1 \\
\hline Problematic weed & & \\
\hline Ipomoea hildebrandtii & 32 & 27 \\
\hline Lantana camara & 86 & 72 \\
\hline Parthenium hysterophorus & 2 & 1 \\
\hline
\end{tabular}

\subsection{INTRODUCTION, MEANS OF SPREAD AND AREA COVERAGE BY P. HYSTEROPHORUS IN RANGELAND}

Pastoralists mentioned not to be aware on the exact introduction of the weed in their grazing land although some mentioned to be the year ranging from 2007 to 2107 (Table 3.3). Moreover, interviewed pastoralists ranked vehicles as the major way of spreading the weed followed by people and livestock (Table 3.3). They explained that, during road construction and maintenance Parthenium seeds were accidentally being transported with construction material. People facilitated the spread of $P$. hysterophorus by unwittingly using it in mattresses as well as growing the plant in their home gardens. Livestock also spread Parthenium weed as they feed on it and then defecate in uninvaded areas, spreading the seeds. According to respondents the area coverage by P. hysterophorus has increased in the area over the last five years and is now present on some of their grazing land (Table 3.3).

Table 3.3: Response of Pastoralists on the Introduction, means of spread and area coverage by $P$. hysterophorus

\begin{tabular}{|c|c|c|}
\hline introduction year & $\mathrm{n}$ & $\%$ \\
\hline Don't know & 97 & 81 \\
\hline 2007 to 2017 & 23 & 19 \\
\hline & & \\
\hline Area coverage by Parthenium weed & & \\
\hline None & 39 & 33 \\
\hline A little or some (<25) & 55 & 46 \\
\hline Moderate (26-50\%) & 22 & 18 \\
\hline Substantial (51-75\%) & 1 & 1 \\
\hline Most (>75\%) & 3 & 2 \\
\hline & & \\
\hline Means of spread & & \\
\hline Livestock & 18 & 15 \\
\hline People & 22 & 18 \\
\hline Vehicles & 54 & 45 \\
\hline Don't know & 26 & 22 \\
\hline
\end{tabular}

\subsection{FEEDING PREFERENCES OF THE LIVESTOCK ON P. HYSTEROPHORUS, EFFECT ON LIVESTOCK AND CONTROL METHODS OF PARTHENIUM WEED}

According to the interviewed pastoralists, feeding preference of cattle on Parthenium hysterophorus to be the leave part of the weed while goats and sheep feeding preferences was on both leaves and flowers (Table 3.4). Although some pastoralists noted the feeding preferences of their livestock on Parthenium weed but some didn't know the preferences (Table 3.4). Moreover, pastoralists reported not to be aware on the changes occurring to their 
Pastoralists' perceptions on an invasive alien plant Parthenium hysterophorus and its management control in Simanjiro District, Tanzania

livestock as a result of feeding on Parthenium weed although some reported changes on their livestock when they feed on Parthenium weed (Table 3.4). The changes included production of less and distasteful milk and diarrhoea (Table 3.4).

Pastoralists reported that, nothing has been done in order to control further spread of Parthenium weed in their grazing land but they normally plough the weed when it occurs in their croplands and around their houses (Table 3.4).

Table 3.4: Livestock's feeding preferences, effect and control methods on P. hysterophorus

\begin{tabular}{|c|c|c|}
\hline Cattle feeding preference & $\mathrm{n}$ & $\%$ \\
\hline Feed on flowers & 18 & 15 \\
\hline Feed on leaves & 63 & 53 \\
\hline Feed on both flowers and leaves & 3 & 2 \\
\hline Don't know & 36 & 30 \\
\hline Goats and sheep feeding preference & & \\
\hline Feed on flowers & 0 & 0 \\
\hline Feed on leaves & 21 & 18 \\
\hline Feed on both flowers and leaves & 33 & 27 \\
\hline Don't know & 66 & 55 \\
\hline Effect on livestock & & \\
\hline Produce less milk & 15 & 13 \\
\hline Produce distasteful milk & 25 & 21 \\
\hline Get diarrhoea & 10 & 8 \\
\hline Nothing & 70 & 58 \\
\hline Control methods & & \\
\hline No control & 104 & 87 \\
\hline Burning & 1 & 1 \\
\hline Slashing/cutting & 1 & 1 \\
\hline Ploughing & 13 & 10 \\
\hline Chemicals/herbicides & 1 & 110 \\
\hline
\end{tabular}

\section{DISCUSSION}

About $81 \%$ of the interviewed pastoralists didn't know introduction time of $P$. hysterophorus in their land in contrast with Clark and Lotter (2011) who reported the introduction of $P$. hysterophorus to be 2010s years. However, about 19\% of the interviewed pastoralists reported the introduction of P. hysterophorus to be around 2007 to 2017 years which supports the report by Clark and Lotter (2011).

Pastoralists (45\%) claimed that vehicles were mainly responsible for the spread of $P$. hysterophorus, especially during road construction and maintenance. They further explained that, during road construction and maintenance $P$. hysterophorus seeds was probably unintentionally carried together with sand from areas where it has infested to new areas. Lakshmi and Srinivas (2007) found P. hysterophorus along roadsides in India, this supports the pastoralists' view that $P$. hysterophorus seeds can be moved together with sand during road construction or maintenance. Furthermore, Hundessa and Belachew (2016) reported that vehicles are important vectors for the movement of $P$. hysterophorus. Also, some of the pastoralists (15\%) mentioned livestock as one of the dispersal agencies for $P$. hysterophorus. Seeds of many weed species are consumed by livestock and spread when deposited in non- infested areas. Therefore, livestock support the spread of $P$. hysterophorus when seeds pass out of the gastro tract though dungs. Additionally, livestock can spread P. hysterophorus unintentionally when seeds attach on their coats and hooves. Navie et al. (2004) reported unintentionally spread of $P$. hysterophorus when the seed get attached on animals' coats and hooves. Moreover, pastoralists (18\%) mentioned people as the means of spread of $P$. hysterophorus as some people unknowingly has been using $P$. hysterophorus as flower for their home garden. 
It was also stated by the pastoralists (46\%) that the area coverage by $P$. hysterophorus has little/some increased to the detriment of other plant species. Also, about $18 \%$ of the interviewed pastoralists reported a moderate increase while 33\% reported that area coverage by P. hysterophorus has not increased. All these might be due to time factor since its introduction or environmental factors has not yet favoured the weed. Although the weed might increase its coverage as time goes due to factors like; ability of the weed to adapt a wide range of climatic condition, ability to produce toxic chemicals which inhibit the growth and germination of other species (Mulatu et al., 2009: Kapoor, 2014). Together with these factors $P$. hysterophorus has also an ability to produce large quantities of light seeds that are easily dispersed by wind, vehicles, livestock, flooding, food grain and fodder (Araya et al., 2015). Furthermore, $P$. hysterophorus has short life cycle (Fatimah and Ahmad, 2009; Knox et al., 2010). Therefore, it is expected with time, $P$. hysterophorus will have been established itself in a large area.

Interviewed pastoralists (58\%) had not seen any changes in their livestock as a result of $P$. hysterophorus; this might be due to the fact that the weed has not yet established itself in a large area or pastoralists are not aware of it. Nevertheless, other pastoralists $(21 \%, 13 \%$ and $8 \%)$ has observed production of distasteful milk, less milk and diarrhoea respectively. This observation is supported by Beyene and Taye (2015); Hundessa and Belachew (2016), that consumption of $P$. hysterophorus results in the production of less and distasteful milk.

There is no major control of $P$. hysterophorus (87\%) in rangelands rather than ploughing (10\%) when it has occurred near around homes and cropland. Although those who did ploughing around homes and in croplands claimed that it is ineffective and time consuming and can't be used in large area. This agrees with Patel (2011) who reported that physical methods such as ploughing have proved ineffective, expensive and time consuming. Also, Khan et al. (2013) reported that manual and mechanical control methods give temporary solutions in the control of P. hysterophorus. Roy and Shaik (2013) suggested that physical, chemical and biological control should be integrated in controlling P. hysterophorus as it is a fast spreading plant. EPPO (2014) mentioned biological control as a costeffective control of $P$. hysterophorus whereas Mekonnen (2017) reported a leaf feeding beetle Zygograma bicolorata as being a successful bio-control.

\section{CONCLUSIONS}

Generally, pastoralists had less information about $P$. hysterophorus regarding its introduction, means of spread, area coverage, effect on livestock as well as its control methods. Therefore, there is a need of conducting an awareness campaign about the weed as pastoralists depends directly on rangeland for livestock production which is the main source of their income. This awareness campaign should also go hand in hand with measures on preventing further spread and effect of the weed in rangeland and country at large. Furthermore, coordination among communities, scientists, governments and non-government organizations should be improved to facilitate the development and implementation of an integrated and sustainable management strategy for the control of $P$. hysterophorus.

\section{SOURCES OF FUNDING}

This research received no specific grant from any funding agency in the public, commercial, or not-for-profit sectors.

\section{CONFLICT OF INTEREST}

The author have declared that no competing interests exist.

\section{ACKNOWLEDGMENT}

The authors gratefully acknowledge the support that was provided by the Unites State Agency for International Development (USAID) through the Centre for Agriculture and Bioscience International (CABI), Nairobi Kenya. We appreciate Tropical pesticides Research Institute (TPRI), Arusha-Tanzania for rendering the materials and human resources that were required to undertake this research. 
Pastoralists' perceptions on an invasive alien plant Parthenium hysterophorus and its management control in Simanjiro District, Tanzania

\section{REFERENCES}

[1] Adkins, S. W. and Navie, S. C. (2006). Parthenium weed: a potential major weed for agro-ecosystems in Pakistan. Weed Science Research 1: 19-36.

[2] Araya, H. Haile, M., Asmelash, A., Edwards, S. and Egziabher, T.B.G. (2015). Overcoming the Challenge of Parthenium hysterophorus through Composting. Journal of Agricultural Science and Food Technology 1 (6): 72-77.

[3] Beyene, H. and Taye, T. (2015). Distribution, Abundance and Socio-Economic Impacts of Parthenium (Parthenium hysterophorus) in Southern Zone of Tigray, Ethiopia. Journal of Poverty, Investment and Development 19: 22-29.

[4] Binu, T., Bharat, B., Maan, B. and Zuzana, M. (2010). Impact of Parthenium hysterophorus L. invasion on plant species composition and soil properties of grassland communities in Nepal 233-240.

[5] Brunel, S., Panetta, D., Fried, G., Kriticos, D., Prasad, R. and Lansink, A.O. (2014). Preventing a new invasive alien plant from entering and spreading in the Euro-Mediterranean region: the case study of Parthenium hysterophorus. European and Mediterranean Plant Protection Organization journal 44(3): 1-11.

[6] Clark, K and Lotter, W. (2011). International Parthenium news. 1-11pp.

[7] Dhileepan, K. (2009). Managing Parthenium weed across diverse landscapes: prospects and limitations. Management of Invasive weeds 5: 227-259.

[8] European and Mediterranean Plant Protection Organization. (2014). Parthenium hysterophorus L. Asteraceae - Parthenium weed.44 (3): 474-478.

[9] Fatimah, H. and Ahmad, T. (2009). Phenology of Parthenium hysterophorus- a key factor for the success of its invasion. Advances in Environmental Biology 3(2): $\quad$ 150-156.

[10] Hundessa, N. and Belachew, K. (2016). Socio-economic impacts of Parthenium hysterophorus l. in East Shewa and West Arsi zones of Ethiopia. International Journal of Agricultural Research Innovation and Technology 6 (2): 5-11.

[11] Huy, L.Q. and Seghal, R.N. (2004). Invasion of Parthenium hysterophorus in Chire-Pine Forests and Its allelopathic effects. Abstracts of an Introduction Workshop on protocols and Methodologies in Allelopathy, April 2-4, 2004 in Palampur (HP) India. CSK HP Agriculture University Palampur (HP) India: p. 52.

[12] Kapoor, R.T. (2012). Awareness related survey of an invasive alien weed, Parthenium hysterophorus L. in Gautam Budh Nagar district, Uttar Pradesh, India. Journal of Agricultural Technology 8(3): 1129-1140.

[13] Kaur, M., Kumar, N., Vikas, K. and Dhiman, R. (2014). Effects and Management of Parthenium hysterophorus: A Weed of Global Significance. International Scholarly Research Notices 12pp.

[14] Kayunze, K.A. (1998). Comparative contribution of non- farm and farm enterprises to rural poverty alleviation in Mbeya Region, Tanzania: A case study of Ileje and Rungwe Districts. Unpublished M.A Dissertation, Sokoine University of Agriculture, Morogoro, Tanzania, pp. 10 - 145.

[15] Kessler, A. and Stroosnijder, S. (2010). Debating land degradation: strategy development for Bolivian mountain valleys. Journal of Land degradation and development 21:480-483.

[16] Kgosikoma, O., Mojaremane, W. and Harvie, B.A. (2012). Pastoralists' perception and ecological knowledge on savannah ecosystem dynamics in semi-arid Botswana. Journal of Ecology and Society 17 (4):27.

[17] Khan, H., Marwat, B. K., Hassan, G. and Muhammad, A.K. (2013). Socio-economic impacts of Parthenium (Parthenium hysterophorus L.) in Peshawar valley, Pakistan. Pakistan Journal of Weed Science Research 19 (3): 275-293.

[18] Kifle, B., Taye, T. and Erine, W. (2011). Competitiveness of Parthenium hysterophorus with other plant species. Ethiopian Journal of Weed Management 4(1): 15-24.

[19] Knox, J., Jaggi, D. and Paul, M.S. (2010). Allelopathic effect of selected weeds on biochemical activity of Parthenium hysterophorus. Journal of Biological Sciences 2(4): 238 - 240.

[20] Kothari, C. R. (2004). Research Methodology: Methods and Techniques. (2nd Ed.), New Age International Publisher Limited, New Delhi, India. 401pp.

[21] Kumar, A. (2014). Parthenium hysterophorus L. and its impact on living world. Indian Journal of Science Research 4 (1): 08-14.

[22] Lakshmi, C. and Srinivas, C.R. (2007). Parthenium: a wide-angle view. Indian Journal of Dermatology, Venerology and Leprology 73: 296-306. 
[23] McConnachie, A.J., Strathie, L.W., Mersie, W., Gebrehiwot, L., Zewdie, K. and Abdurehim, A. (2011). Current and potential geographical distribution of the invasive plant Parthenium hysterophorus (Asteraceae) in eastern and southern Africa. Weed Research Journal 51 (1): 71-84.

[24] Mulatu, W., Gezahegn, B., Solomon, T. (2009). Allelopathic effects of an invasive alien weed Parthenium hysterophorus L. compost on lettuce germination and growth. African Journal of Agricultural Research 4(11): $1325-1330$.

[25] Navie, S.C., Puntta. F.D., McFadyen, R.E. and Adkins, S.W. (2004). Germinable soil seed banks of Central Queensland rangelands invaded by the exotic weed Parthenium hysterophorus. Seed Biology and Management, 4: 154-167.

[26] Nyaruhucha, C.N.M., Musya, J.M., Mamiro, P.S. and Kerengi, A.J. (2006). Nutritional status and feeding practices of under five children in Simanjiro District, Tanzania. Tanzania Health Research Bulletin 8, 162-167.

[27] Oba, G. and Kaitira, L.M. (2006). Herder knowledge of landscape assessments in arid rangelands in northern Tanzania. Journal of Arid Environments 66: 168-186.

[28] Patel, S. (2011). Harmful and beneficial aspects of Parthenium hysterophorus. Journal of Biotechnology 3(1): 1-9.

[29] Roy, C. D. and Shaik, M. M. (2013). Toxiology, Phytochemistry, Bioactive compounds and Pharmacology of Parthenium hysterophorus. Journal of Medicinal Plant Studies 1 (3): 126-141.

[30] Sangeda, A. Z. and Malole J. L. (2014) Tanzanian rangelands in a changing climate: Impacts, adaptations and mitigation. Journal of Agricultural Science 2(1): 1-10.

[31] Steven, N. and Rob, A. (2002). A participatory approach to assessing the impact of a community-based animal health project with Maasai communities in Tanzania. 4: 17-45.

[32] Yanda, P.Z. and William, C. (2010) Livelihoods diversifications and implications on food security and poverty levels in the Maasai plains: The case of Simanjiro district, Northern Tanzania. African Journal of Environmental Science and Technology4(3): 154-166. 